\title{
Pengaruh Ratio Keuangan dan Good Corporate Governance terhadap Peringkat Obligasi pada Perusahaan Pertambangan
}

\author{
Lukman Hakim \\ STIE Syariah Bengkalis \\ lukman_hakim94@ymail.com \\ Bambang Supeno \\ Universitas Lancang Kuning \\ Bambang.supeno@unilak.ac.id
}

\begin{abstract}
Abstrak
Tujuan penelitian untuk menganalisis pengaruh rasio keuangan dan corporate governance terhadap peringkat obligasi pada perusahaan pertambangan yang terdaftar di Bursa Efek Indonesia. Sampel penelitian ini adalah seluruh perusahaan pertambangan yang terdaftar di Bursa Efek Indonesia periode tahun 2010-2014 yang berjumlah 11 perusahaan. Teknik analisis penelitian yang digunakan adalah menggunakan persamaan regresi logistik Berdasarkan hasil penelitian dengan uji regresi logistik secara parsial terdapat pengaruh yang signifikan antara Return On Assets terhadap peringkat obligasi pada perusahaan Pertambangan. Berdasarkan hasil pengolahan data diperoleh nilai koefisien determinasi (R2) sebesar 0,522. Hal ini menunjukkan bahwa Return On Assets, Total Assets Turn Over dan Kepemilikan Institutional secara simultan memberikan pengaruh sebesar 52,2\% terhadap Peringkat Obligasi

Kata kunci Return On Assets, Total Assets Turn Over dan Kepemilikan Institutional, Peringkat Obligasi

Abstract The research objective is to analyze the effect of financial ratios and corporate governance on bond ratings on mining companies listed on the Indonesia Stock Exchange. The sample of this research is all mining companies listed on the Indonesia Stock Exchange in the period 2010-2014, amounting to 11 companies. The research analysis technique used is to use the logistic regression equation. Based on the results of the study with the partial logistic regression test there is a significant influence between Return On Assets on the bond rating of the Mining company. Based on the results of data processing obtained value of the coefficient of determination (R2) of 0.522. This shows that Return On Assets, Total Assets Turn Over and Institutional Ownership simultaneously have an effect of $52.2 \%$ on the Bond Rating
\end{abstract}

Keywords $\quad$ Return On Assets, Total Assets Turn Over and Institutional Ownership, Bond Rating

\section{PENDAHULUAN}

Keberadaan pasar modal merupakan wadah yang dapat digunakan untuk para investor dan perusahaan. Berbagai instrumen keuangan dapat digunakan sebagai pilihan untuk menginvestasikan dana. Investasi pada pasar modal dibagi menjadi dua jenis yaitu Investasi dalam surat kepemilikan (saham) dan investasi dalam surat hutang (obligasi). Kegiatan investasi pada aset keuangan semakin menarik minat masyarakat pada akhir-akhir ini. Hal ini terjadi karena 
dengan semakin meningkatnya kegiatan investasi dibutuhkan dana yang besar sementara banyak anggota masyarakat yang memiliki surplus dana menginginkan peningkatan nilai dari dana yang dimilikinya. Oleh karena itu ketika penggunaan dari modal internal perusahaan seperti laba yang ditahan, agio saham, sudah tidak bisa menutupi kebutuhan dana perusahaan banyak perusahaan mencari dana dari masyarakat luas (go public) melalui pasar modal.

Pasar modal merupakan salah satu sarana untuk melakukan investasi karena memungkinkan para investor melakukan investasi guna membentuk portfolio sesuai dengan resiko yang bersedia mereka tanggung dengan tingkat yang diharapkan. Banyak investor lebih tertarik menanamkan modalnya pada obligasi hal ini dikarenakan volalitas obligasi dibandingkan dengan saham lebih rendah. Hal lain yang menarik investor lebih memilih obligasi adalah resiko perusahaan tidak mampu memenuhi kewajibannya membayar bunga dan pokok pinjaman. Ketidakmampuan ini dipengaruhi oleh kinerja perusahaan penerbit obligasi.

Obligasi merupakan sumber pendanaan bagi pemerintah dan perusahaan yang sebagian besar diperoleh dari pasar modal. Secara sederhana, obigasi merupakan suatu surat berharga yang dikeluarkan oleh penerbit (isuer) kepada investor, dimana penerbit akan memberikan suatu imbal hasil (return) berupa kupon yang dibayarkan secara berkala dan nilai pokok (principal) ketika obligasi tersebut telah jatuh tempo. Investasi pada surat berharga obligasi menjadi pilihan yang mulai banyak dilirik oleh investor di Indonesia, semenjak maraknya perusahaan-perusahaan yang menerbitkan obligasi sebagai salah satu sumber pendanaannya untuk melakukan investasi pada obligasi, selain diperlukan dana yang cukup, pemilik modal juga memerlukan pengetahuan yang cukup tentang obligasi serta diikuti dengan naluri bisnis yang baik untuk bisa menganalisis atau memperkirakan faktor-faktor yang bisa mempengaruhi investasi pada obligasi.

Tujuan dan manfaat dari proses pemeringkatan obligasi adalah memberikan informasi akurat mengenai kinerja keuangan, posisi bisnis perusahaan, baik bagi investor maupun terhadap perusahaan yang menerbitkan surat obligasi berupa Rekomendasi investasi, Perbandingan dan Informasi Resiko Investasi (Juarsa Badri, 2015:188). Agen pemeringkatan tidak menyebutkan lebih lanjut bagaimana laporan keuangan dapat digunakan dalam menentukan peringkat obligasi. Faktor yang dapat mempertimbangkan agen pemeringkat dalam menentukan pemeringkat suatu obligasi diantaranya adalah berbagai rasio keuangan dalam penelitian ini yaitu Total Asset Turnover dan Return On asset serta indentiture agreements sebagai perlidungan terhadap aset yang ada kualitas manajemen.

Tabel 1: Data Laporan Perusahaan Pertambangan

\begin{tabular}{|c|c|c|c|c|c|c|c|c|c|c|c|c|c|c|c|}
\hline \multirow[t]{2}{*}{ Nama Perusahaan } & \multicolumn{5}{|c|}{ ROA } & \multicolumn{5}{|c|}{ TAT } & \multicolumn{5}{|c|}{ K.Institusional } \\
\hline & 2010 & 2011 & 2012 & 2013 & 2014 & 2010 & 2011 & 2012 & 2013 & 2014 & 2010 & 2011 & 2012 & 2013 & 2014 \\
\hline $\begin{array}{l}\text { PT. Aneka Tambang } \\
\text { (Persero), Tbk }\end{array}$ & 13,71 & 12,68 & 15,19 & 1,87 & $-3,08$ & 0,31 & 0,68 & 0,53 & 0,52 & 0,19 & 0,8 & 0,8 & 0,8 & 0,8 & 0,8 \\
\hline PT. Adaro Energy Tbk & 5,46 & 9,76 & 5,73 & 3,40 & 2,49 & 0,61 & 0,70 & 0,55 & 0,49 & 0,24 & 0,44 & 0,44 & 0,44 & 0,44 & 0,44 \\
\hline PT. Bumi Resources, Tbk & 0,19 & 2,92 & $-9,59$ & $-9,42$ & 1,92 & 0,50 & 0,54 & 0,51 & 0,51 & 0,23 & 0,18 & 0,19 & 0,18 & 0,18 & 0,18 \\
\hline $\begin{array}{l}\text { PT. Medco International } \\
\text { Energi, Tbk }\end{array}$ & 3,87 & 3,87 & 0,71 & 0,63 & 0,44 & 0,41 & 0,44 & 0,35 & 0,14 & 0,14 & 0,67 & 0,67 & 0,66 & 0,66 & 0,66 \\
\hline PT. Elnusa ,Tbk & 1,74 & 14,57 & 0,16 & 4,31 & 4,31 & 1,14 & 1,07 & 1,11 & 0,49 & 0,49 & 0,34 & 0,18 & 0,17 & 0,17 & 0,17 \\
\hline PT. Bukit Asam, Tbk & 22,92 & 26,84 & 26,84 & 15,88 & 9,64 & 0,91 & 0,92 & 0,91 & 0,95 & 0,53 & 0,59 & 0,59 & 0,59 & 0,59 & 0,59 \\
\hline $\begin{array}{l}\text { PT. Energi Mega Persada } \\
\text {,Tbk }\end{array}$ & $-0,54$ & 1,00 & 1,33 & 7,48 & 1,31 & 0,11 & 0,122 & 0,31 & 0,35 & 0,18 & 0,5 & 0,5 & 0,5 & 0,5 & 0,5 \\
\hline PT. Bayan Resources, Tbk & 9,33 & 13,02 & 2,88 & $-3,52$ & $-0,71$ & 1,58 & 0,92 & 0,74 & 0,73 & 0,31 & 0,64 & 0,64 & 0,64 & 0,64 & 0,64 \\
\hline PT. Timah Persero ,Tbk & 16,12 & 13,65 & 7,07 & 0,53 & 2,58 & 1,42 & 1,33 & 1,28 & 0,74 & 0,35 & 0,65 & 0,65 & 0,65 & 0,65 & 0,65 \\
\hline $\begin{array}{l}\text { PT. Indo Tambang Raya } \\
\text { Megah ,Tbk }\end{array}$ & 18,73 & 34,60 & 28,97 & 16,56 & 10,88 & 1,53 & 1,51 & 1,63 & 1,56 & 0,71 & 0,22 & 0,02 & 0,02 & 0,02 & 0,02 \\
\hline $\begin{array}{l}\text { PT. Perusahaan Gas } \\
\text { Negara, Tbk }\end{array}$ & 20,14 & 19,75 & 23,42 & 20,49 & 0,85 & 0,62 & 0,63 & 0,66 & 0,66 & 0,30 & 0,45 & 0,57 & 0,57 & 0,57 & 0,57 \\
\hline
\end{tabular}


Sumber: data olahan 2020

\section{LANDASAN TEORI}

\subsection{Peringkat Obligasi}

Peringkat obligasi merupakan simbol-simbol karakter yang diberikan oleh agen peringkat untuk menunjukkan risiko dari obligasi (Hartono, 2009). Peringkat obligasi dipengaruhi oleh (1) Proporsi modal terhadap hutang, (2) Tingkat profitabilitas perusahaan atau pihak yang menerbitkan obligasi, (3) Tingkat kepastian dalam menghasilkan pendapatan, (4) Besar kecilnya perusahaan atau pihak yang menerbitkan obligasi, (5) Jumlah pinjaman subordinasi yang dikeluarkan perusahaan atau pihak yang menerbitkan obligasi (Rahardjo, 2003).

Peringkat obligasi merupakan indikator ketepat waktuan pembayaran pokok dan bunga utang obligasi. Selain itu, peringkat obligasi prediksi skala risiko dari semua obligasi yang diperdagangkan. Dengan demikian peringkat obligasi menunjukkan skala keamanan obligasi dalam membayar kewajiban pokok dan bunga secara tepat waktu. Semakin tinggi peringkat, semakin menunjukkan bahwa obligasi tersebut terhindar dari risiko default.

Peringkat obligasi diterbitkan oleh lembaga pemeringkat yang independen. Di Indonesia terdapat dua lembaga pemeringkat sekuritas utang, yaitu PT PEFINDO (Pemeringkat Efek Indonesia) dan Kasnic Credit Rating Indonesia. Lembaga-lembaga pemeringkat ini memudahkan para investor dalam memberikan informasi investasi mengenai kemampuan ekonomi dan finansial penerbit (issuer) obligasi. Peringkat obligasi yang dilakukan oleh lembaga pemeringkat memberikan gambaran tentang kredibilitas (credit worthiness) dan mempengaruhi penjualan obligasi tersebut.

Tabel 2. Peringkat Obligasi

\begin{tabular}{|c|c|c|}
\hline Moody's & $S \& P$ & Arti \\
\hline Aaa & AAA & $\begin{array}{l}\text { Kualitas terbaik, dengan resiko kecil, penerbitnya stabil dan } \\
\text { dapat diandalkan }\end{array}$ \\
\hline $\mathrm{Aa}$ & AA & $\begin{array}{l}\text { Kualitas lebih tinggi, dengan resiko jangka panjang yang } \\
\text { sedikit lebih tinggi }\end{array}$ \\
\hline A & A & $\begin{array}{l}\text { Kualias tinggi hingga menengah, dengan banyak atribut } \\
\text { kuat, tetapi agak rentan terhadap kondisi perekonomian }\end{array}$ \\
\hline Baa & BBB & $\begin{array}{l}\text { Kualitas menengah, jangka pendek memadai, tetapi kurang } \\
\text { dapat diandalkan untuk jangka panjang }\end{array}$ \\
\hline $\mathrm{Ba}$ & $\overline{B B}$ & $\begin{array}{l}\text { Ada unsur spekulatif, dengan tingkat keamanan yang } \\
\text { moderat, tetapi tidak ada jaminn keamanan. }\end{array}$ \\
\hline B & B & $\begin{array}{l}\text { Mampu membayar sekarang, tetapi dengan resiko macet } \\
\text { dimasa yang akan datang. }\end{array}$ \\
\hline Caa & $\mathrm{CCC}$ & $\begin{array}{l}\text { Kualitas rendah, bahaya nyata kegagalan di masa yang akan } \\
\text { datang. }\end{array}$ \\
\hline $\mathrm{Ca}$ & $\mathrm{CC}$ & Kualitas yang berspekulasi tinggi, acapkali gagal. \\
\hline $\mathrm{C}$ & $\mathrm{C}$ & $\begin{array}{l}\text { Urutan terendah, prospek pembayaran kembali rendah } \\
\text { meskipun mungkin masih bisa terbayar }\end{array}$ \\
\hline $\mathrm{K}$ & $\mathrm{K}$ & Tidak mapu membayar bunga \\
\hline
\end{tabular}

Sumber : Irham Fahmi, (2013:184)

\subsection{Return On Asset}

Return On asset (ROA) adalah rasio yang mengukur efisiensi pengendalian harga pokok atau biaya produksinya, mengindikasikan kemampuan perusahaan untuk berproduksi secara efisien. Dalam mengevaluasi dapat dilihat margin per unit produk, bila rendah maka perusahaan 
tersebut sensitif terhadap pesaingnya. Menurut Hamdi (2012:68) Return on Asset merupakan kemampuan dari modal yang diinvestasikan dalam keseluruhan aktiva untuk menghasilkan keuntungan neto.

Menurut Lukman (2019:35) Return On Asset merupakan pengukuran kemampuan perusahaan secara keseluruhan di dalam menghasilkan keuntungan dengan jumlah keseluruhan aktiva yang tersedia di dalam perusahaan. Return On Asset yang negatif disebabkan laba perusahaan dalam kondisi negatif (Rugi). Hal ini menunjukkan kemampuan dari modal yang diinvestasikan secara keseluruhan aktiva belum mampu menghasilkan laba.

Secara matematis ROA dapat dirumusan sebagai berikut:

\subsection{Total Assets Turnover (TAT)}

$$
R O A=\frac{\text { Laba Bersih }}{\text { Total Aktiva }}
$$

TAT merupakan rasio yang menunjukkan efektivitas penggunaan seluruh harta perusaahaan dalam rangka menghasilkan penjualan atau menggambarkan berapa rupiah penjualan bersih yang dapat dihasilkan oleh setiap rupiah yang diinvestasikan dalam bentuk harta perusahaan. Kalau perputarannya lambat, ini menunjukkan bahwa aktiva yang dimiliki terlalu besar dibandingkan dengan kemampuan untuk menjual.

Menurut Silva \& Sri Mega (2017) Total Assets Turnover merupakan rasio yang digunakan untuk mengukur kefektifan total aset yang dimiliki perusahaan dalam menghasilkan penjualan, atau dengan kata lain untuk mengukur berapa jumlah penjualan yang akan dihasilkan dari setiap rupiah dana yang tertanam dalam total aset. Semakin tinggi aktivitas perusahaan maka kemungkinan besar obligasi perusahaan masuk investment grade, karena dengan penjualan yang tinggi cenderung lebih mampu menghasilkan laba yang tinggi. Secara matematis TAT dapat dirumuskan sebagai berikut:

$$
T A T=\frac{\text { Penjualan }}{\text { Total Aktiva }}
$$

\subsection{Good Corporate Governance}

Institusi merupakan sebuah lembaga yang memiliki kepentingan besar terhadap investasi yang dilakukan termasuk investasi saham. Sehingga biasanya institusi menyerahkan tanggung jawab pada divisi tertentu untuk mengelola investasi perusahaan tersebut. Kepemilikan institutional merupakan kepemilikan saham dalam suatu perusahaan publik yang dimiliki oleh perusahaan-perusahaan besar lainnya, seperti bank, atau institusi tertentu yang dapat mengontrol operasi atau kebijakan perusahaan.

Good Corporate governance adalah sistem kontrol, peraturan, dan insentif yang dirancang untuk meminimalkan biaya keagenan antara manajer dan investor serta mencegah kecurangan perusahaan, merupakan sebuah konflik kepentingan dan upaya untuk meminimalkannya (Berk \& DeMarzo, 2007). Menurut Ayu (2012:3) mekanisme Corporate Governance merupakan suatu sistem yang mampu mengendalikan dan mengarahkan kegiatan operasional perusahaan serta pihak-pihak yang terlilbat didalamnya, sehingga dapat digunakan untuk menekan terjadinya masalah keagenan.

Good Corporate governance dalam penelitian ini adalah kepemilikan Institusi, yaitu merupakan persentase saham yang dimiliki perusahaan tersebut.

Berdasarkan penjelasan di atas, maka model penelitian ini dapat digambarkan sebagai berikut: Gambar 1. Model Penelitian 


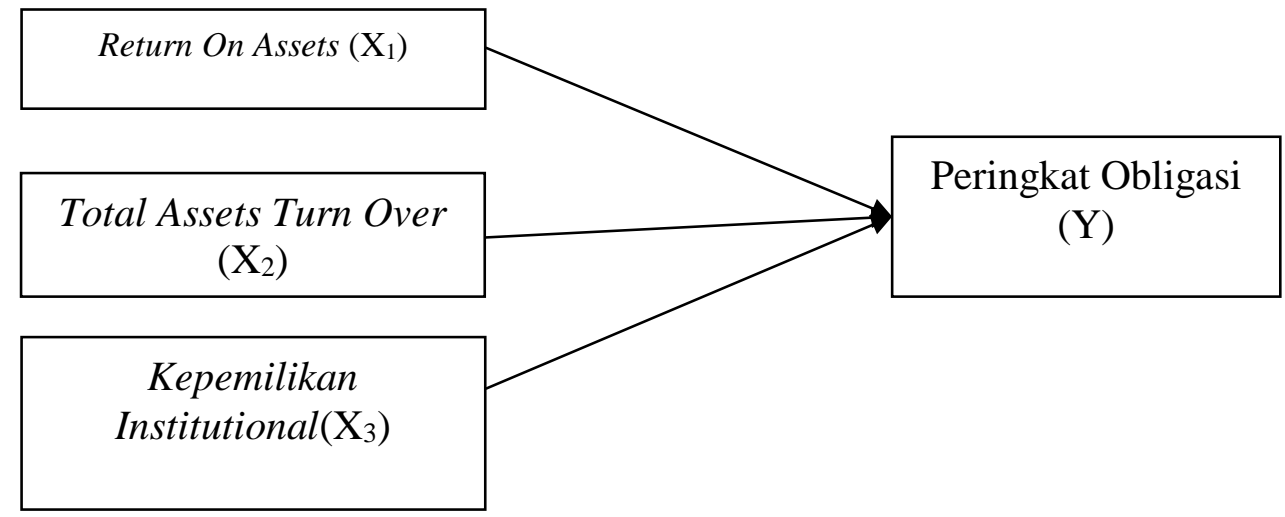

\section{METODOLOGI PENELITIAN}

\subsection{Populasi dan Sampel}

Populasi adalah keseluruhan objek penelitian. Menurut Citra (2012) Populasi juga diartikan sebagai totalitas semua nilai yang mungkin dihitung ataupun pengukuran kuantitatif mengenai karakteristik tertentu dari semua anggota kumpulan lengkap dan jelas dipelajari sifatnya. Populasi dalam penelitian ini adalah perusahaan - perusahaan pertambangan yang tercatat di Bursa Efek Indonesia (BEI) tahun 2010 - 2014 dan memiliki peringkat obligasi pada PT. PEFINDO di tahun 2010 - 2014

Sampel adalah sebagian atau wakil dari populasi yang diteliti. Pemilihan sampel dilakukan dengan metode purposive sampling, dimana populasi yang akan dijadikan sampel penelitian ini merupakan populasi yang memenuhi kriteria sampel tertentu sesuai dengan yang dikehendaki oleh peneliti dan disesuaikan dengan tujuan penelitian.

Dalam penelitian ini sampel yang diambil dari populasi didasarkan pada kriteria sebagai berikut:

1. Merupakan perusahaan Pertambangan yang terdaftar di Bursa Efek Indonesia tahun 2010 - 2014

2. Obligas memiliki peringkat obligasi yang dikeluarkan oleh PT. PEFINDO

3. Perusahaan memiliki laporan keuangan lengkap selama periode terpilih.

4. Perusahaa dalam bidang pertambangan yang memiliki obligasi aktif selama tahun 2010 2014

5. Perusahaan tersebut merupakan perusahaan (Tbk)

6. Menerbitkan laporan CGC

7. Perusahaan yang dijadikan sampel memiliki laporan keuangan yang lengkap dan jelas untuk periode terpilih

Tabel 3. Penentuan Jumlah Sampel

\begin{tabular}{|l|c|}
\hline \multicolumn{1}{|c|}{ Kriteria sampel } & Jumlah perusahaan \\
\hline Perusahaan yang aktif mengeluarkan obligasi & 39 \\
\hline Data yang tidak lengkap & $(28)$ \\
\hline Total sampel & 11 \\
\hline Tahun pengamatan & 5 \\
\hline Total sampel selama tahun pengamatan & 55 \\
\hline
\end{tabular}

Sumber : Data olahan

Sampel yang diambil sebagai penelitian adalah perusahaan yang menerbitkan obligasi dan diberi peringkat oleh Pefindo dari periode 2010 sampai dengan 2014. 
Tabel 4. Sampel Penelitian

\begin{tabular}{|c|l|c|}
\hline No & \multicolumn{1}{|c|}{ Nama Emiten } & Kode \\
\hline 1 & PT. Adaro Energy Tbk & ADRO \\
\hline 2 & PT. Aneka Tambang (Persero), Tbk & ANTM \\
\hline 3 & PT. Bumi Resources, Tbk & BUMI \\
\hline 4 & PT. Bayan Resources, Tbk & BYAN \\
\hline 5 & PT. Elnusa ,Tbk & ELSA \\
\hline 6 & PT. Energi Mega Persada ,Tbk & ENRG \\
\hline 7 & PT. Indo Tambang Raya Megah ,Tbk & ITMG \\
\hline 8 & PT. Medco International Energi, Tbk & MEDC \\
\hline 9 & PT. Perusahaan Gas Negara, Tbk & PGAS \\
\hline 10 & PT. Bukit Asam, Tbk & PTBA \\
\hline 11 & PT. Timah Persero,Tbk & TINS \\
\hline
\end{tabular}

Sumber : Indonesian Capital Market Directory

\subsection{Teknik Analisa Data}

Dalam teknik analisis ini tidak memerlukan lagi uji normalitas dan uji asumsi klasik pada variabel bebasnya (Ghozali, 2012). Karena pada regresi logistik mengabaikan heteroscedasity, artinya variabel dependen tidak memerlukan hemoscedascy untuk masing-masing variabel independennya. Dengan demikian model analisis dapat dinyatakan sebagai berikut:

Rumus : $\operatorname{Ln} P /((1-P))=\alpha+\beta \_1 X_{-} 1+\beta \_2 X \_2+\beta \_3 X \_3+\varepsilon$

$\operatorname{Ln} \frac{\mathrm{P}}{(1-\mathrm{P})} \quad=1$, jika peringkat obligasi termasuk investment grade (memiliki peringkat AAA,

$\operatorname{Ln} \frac{\mathrm{P}}{(1-\mathrm{P})} \quad=0$, jika peringkat obligasi termasuk non investment grade (memiliki peringkat $\mathrm{BB}$,

$$
\text { B CCC, D) }
$$

$\alpha \quad=$ konstanta

$\beta_{1} \beta_{2} \beta_{3} \quad=$ koefisien regresi

$\mathrm{X}_{1} \quad=$ Return On Assets

$\mathrm{X}_{2} \quad=$ Total Assets Turn Over

$\mathrm{X}_{3} \quad=$ Kepemilikan Institutional

$\varepsilon \quad=$ error

Adapun alat analisis yang digunakan adalah analisis berikut beberapa uji yang digunakan untuk menilai sesuatu penelitian tersebut tepat atau tidak diteliti dengan model regresi logistik:

\section{a. Menilai Model Fitting}

Jika nilai - $2 \log \mathrm{L}<0,05$ berarti bahwa model fit dengan data.

Jika nilai - $2 \log L>0,05$ berarti bahwa model tidak fit dengan data.

Adanya pengurangan nila antara - 2LogL awal (initial -2LL fungcion) dengan nilai 2LogL pada langkah berikutnya menunjukkan bahwa model yang dihipotesiskan fit dengan data (Ghozali, 2012:361).

b. Menilai Kelayakan Regresi (Goodnes Of Fit)

Uji goodnes of fit atau uji keselarasan adalah perbandingan antara frekuensi observasi dengan frekuensi harapan. apabilah nilai Goodnes Of fit test $>0,05$ model yang terbentuk fit atau layak digunakan. 


\section{HASIL PENELITIAN}

\subsection{Uji Kelayakan}

a. Menilai Keseluruhan Model

Analisis pertama yang dilakukan adalah menguji keseluruhan model (overall model fit). Pengujian ini dilakukan dengan membandingkan nilai antara -2 Loglikehood awal (intercept only) dengan -2 Loglikehood pada model final. Adanya pengurangan nilai antara -2 Loglikehood awal (intercept only) dengan nilai -2 Loglikehood pada model final menunjukkan bahwa model fit dengan data.

Tabel 5. -2 Log Likehood (Block Number $=0$ )

\begin{tabular}{|ll|r|r|}
\hline & & & \\
\cline { 4 - 4 } Iteration & & Coefficients \\
\cline { 4 - 4 } Step 0 0 & 1 & 35,931 & Cog likelihood \\
& 2 & 33,600 & 1,636 \\
& 3 & 33,510 & 2,165 \\
& 4 & 33,510 & 2,295 \\
& 5 & 33,510 & 2,303 \\
& & 2,303 \\
\hline
\end{tabular}

Sumber : Hasil Olahan Penulis

Tabel 6. -2 Log Likehood (Block Number $=1$ )

Iteration History $\mathbf{a}, \mathbf{b}, \mathbf{c}, \mathbf{d}$

\begin{tabular}{|c|c|c|c|c|c|c|}
\hline \multirow{2}{*}{\multicolumn{2}{|c|}{ Iteration }} & \multirow{2}{*}{$\begin{array}{c}-2 \log \\
\text { likelihood }\end{array}$} & \multicolumn{4}{|c|}{ Coefficients } \\
\hline & & & Constant & $\mathrm{X} 1$ & $\mathrm{X} 2$ & $\mathrm{X} 3$ \\
\hline Step 1 & 1 & 34,983 & 1,405 & ,003 &, 350 &,- 100 \\
\hline & 2 & 31,291 & 1,662 & 011 & ,740 &,- 196 \\
\hline & 3 & 25,923 & 1,673 & ,085 & ,118 &,- 094 \\
\hline & 4 & 20,616 & 1,890 & 235 & $-1,067$ & ,072 \\
\hline & 5 & 18,931 & 2,081 & ,339 & $-1,170$ & 091 \\
\hline & 6 & 18,570 & 2,091 & 408 &,- 976 & ,035 \\
\hline & 7 & 18,542 & 2,071 & ,433 &,- 845 &,- 009 \\
\hline & 8 & 18,541 & 2,069 & 436 &,- 830 &,- 014 \\
\hline & 9 & 18,541 & 2,069 & ,436 &,- 830 &,- 014 \\
\hline
\end{tabular}

Sumber : Hasil Olahan Penulis

Berdasarkan tabel 6, di atas model dengan intercept saja menghasilkan -2 log likelihood 33,510, sedangkan jika variabel Return On Assets, Total Assets Turn Over dan Kepemilikan Institutional kedalam model, maka nilai likelihood turun menjadi 18,541 dengan nilai signifikan $0,000<0,05$ yang artinya model model Fit dengan data.

b. Menilai Kelayakan Model Regresi (Goodness Of Fit)

Kelayakan model regresi dinilai dengan menggunakan Hosmer-Lameshow Goodness of Fit Test.

Tabel 7. Goodness Of Fit Hosmer and

Lemeshow Test

\begin{tabular}{|l|r|r|r|}
\hline Step & Chi-square & df & Sig. \\
\hline 1 & 10,970 & & 7 \\
\hline
\end{tabular}

Sumber : Hasil olahan Penulis

Berdasarkan tabel 7 menunjukkan nilai Hosmer and Lemeshow Test diperoleh sebesar 10,970 dengan signifikan 0,140 yang berarti bahwa nilai signifikannya lebih besar dari 0,05 
sehingga model bisa dikatakan fit, serta mampu memprediksi nilai observasinya atau dapat dikatakan model dapat diterima karena cocok dengan data observasinya.

c. Uji Koefisien Determinasi

Nilai koefisien determinasi dapat dilihat pada nilai Nagelkerke $R$ Square.

Tabel 8. Koefisien Determinasi

\begin{tabular}{|l|r|r|r|}
\hline Step & -2 Log likelihood & Cox \& Snell R Square & Nagelkerke R Square \\
\hline 1 & $18,541^{\mathrm{a}}$ &, 238 &, 522 \\
\hline
\end{tabular}

Sumber : Hasil Olahan Penulis

Berdasarkan tabel 8, hasil uji koefisien determinasi diatas terlihat bahwa nilai Cox \& Snell $R$ Square sebesar 0,331 dan nilai Nagelkerke $R$ Square adalah 0,522 yang berarti bahwa variabilitas yang terjadi pada variabel terikat yaitu peringkat obligasi yang dibedakan menjadi investment grade dan non investment grade dapat dijelaskan oleh variabilitas variabel bebasnya yaitu Return On Assets, Total Assets Turnover dan kepemilikan institutional sebesar 52,2\%, sedangkan sisanya sebesar 47,8\% dijelaskan oleh variasi variabel lainnya diluar model.

\section{Pengujian Regresi Logistik}

Dalam penelitian ini menggunakan teknik analisis data regresi logistik atau regresi logit.

Tabel 9. Tabel Hasil Regresi Logistik

Variables in the Equation

\begin{tabular}{|ll|r|r|r|r|r|r|}
\hline & \multicolumn{1}{|c|}{ B } & \multicolumn{1}{|c|}{ S.E. } & \multicolumn{1}{|c|}{ Wald } & df & \multicolumn{1}{c|}{ Sig. } & Exp(B) \\
\hline Step 1 $1^{\text {a }}$ & X1 &, 436 &, 190 & 5,255 & 1 &, 022 & 1,546 \\
& X2 &,- 830 & 2,263 &, 135 & 1 &, 714 &, 436 \\
& X3 &,- 014 &, 873 &, 000 & 1 &, 987 &, 986 \\
& Constant & 2,069 & 1,132 & 3,342 & 1 &, 068 & 7,917 \\
\hline
\end{tabular}

Sumber : Hasil Olahan Penulis

Berdasarkan hasil pengujian yang terdapat pada tabel 9, maka diperoleh persamaan sebagai berikut:

$$
\mathrm{Y}=2,069+0,436 \mathrm{X}_{1}-0,830 \mathrm{X}_{2}-0,014 \mathrm{X}_{3}+\varepsilon
$$

a. Pengaruh Return On Assets Terhadap Peringkat Obligasi

Berdasarkan hasil regresi Logistik Return On Assets memiliki nilai signifikan sebesar 0,022 $<0,05(\alpha)$, maka $H_{0}$ ditolak dan $H_{1}$ diterima. Artinya Return On Assets memiliki pengaruh terhadap peringkat obligasi pada perusahaan Pertambangan yang terdaftar di Bursa Efek Indonesia.

b. Pengaruh Total Assets Turn Over Terhadap Peringkat Obligasi

Berdasarkan hasil regresi Logistik Total Assets Turn Over Memiliki nilai signifikan sebesar $0,714>0,05(\alpha)$, maka $H_{0}$ diterima dan $H_{2}$ ditolak, artinya Saldo Laba tidak memiliki pengaruh terhadap peringkat obligasi pada perusahaan Pertambangan yang terdaftar di Bursa Efek Indonesia.

c. Pengaruh Kepemilikan Institutional Terhadap Peringkat Obligasi

Berdasarkan hasil regresi Logistik Kepemilikan Institutional Memiliki nilai signifikan sebesar 0,986 >0,05 $(\alpha)$, maka $H_{0}$ diterima dan $H_{3}$ ditolak, artinya Kepemilikan Institutional tidak memiliki pengaruh terhadap peringkat obligasi pada perusahaan Pertambangan yang terdaftar di Bursa Efek Indonesia.

\section{Pembahasan}

a. Pengaruh Return On Assets Terhadap Peringkat Obligasi

Investasi dalam bentuk obligasi secara langsung sebenarnya tidak terpengaruh oleh profitabilitas perusahaan, karena berapapun besarnya profit yang mampu dihasilkan oleh 
perusahaan, pemegang obligasi tetap menerima sebesar tingkat bunga yang telah ditentukan. Namun, para analisis tetap tertarik terhadap profitabilitas perusahaan karena profitabilitas mungkin merupakan satu-satunya indikator yang paling baik mengenai kesehatan keuangan perusahaan. Apabila laba perusahaan tinggi, akan memberikan peringkat yang naik pula sehingga dikatakan dapat mempengaruhi prediksi peringkat obligasi.

Variabel Return On Assets menunjukkan hasil berpengaruh positif terhadap peringkat obligasi. Dimana variabel Return On Assets dalam hal ini menunjukkan kemampuan perusahaan dalam menghasilkan laba perusahaan. Dengan kemampuannya yang tinggi dalam menghasilkan laba, maka perusahaan dapat meningkatkan peringkatnya dan dapat meyakinkan para investor untuk membeli obligasi yang dikeluarkan oleh perusahaan.

Return On Assets yang dimiliki oleh perusahaan Pertambangan setiap tahunnya cenderung menurun. Namun, Return On Assets diperusahaan tersebut cukup besar. Sehingga para kondisi ini menarik kepercayaan para investor. Ini juga disebabkan oleh meningkatnya aktiva perusahaan yang merupakan investasi sehingga laba yang diperoleh perusahaan cukup baik.

PT. Aneka Tambang Persero memiliki ROA yang cukup baik setiap tahun. Tetapi pada tahun 2014 ROA yang dimiliki sebesar -3,08, ini dikarenakan penurunan penjualan pada perusahaan tersebut secara drastis. PT. Adaro Energy memiliki ROA yang meningkat, Tetapi pada tahun 2011 terjadi penurunan dan dikuti dengan tahun selanjutnya. PT. Bumi Resources memiliki ROA yang cukup buruk setiap tahunnya. Ini disebabkan perusahaan tersebut mempunyai hutang yang cukup banyak sehingga terjadi penurunan yang drastis pada peringkat obligasi tersebut.

PT. Medco International Energi memiliki ROA yang cukup bagus setiap tahunnya. Tetapi pada tahun 2012 sampai 2014 memiliki ROA yang turun setiap tahunnya karena perusahaan tersebut memliki penjualan yang rendah. PT. Elnusa ROA yang sangat baik terdapat pada tahun 2011, Tetapi pada tahun 2012 ROA tersebut menurun drastis dan ini sangat berpengaruh pada peringkat obligasi tersebut.

PT. Bukit Asam memiliki ROA yang sangat baik dan meningkat setiap tahunnya, Tetapi pada tahun 2014 ROA tersebut cenderung menurun ini diakibatkan toal aktiva yang dikeluarkan tidak seimbang dengan total penjualan yang terjadi pada tahun tersebut. PT. Energi Mega Persada terdapat ROA yang sangat menurun terjadi pada tahun 2010 yaiu sebesar $-0,54$. Ini diakibatkan penurunan penjualan pada perusahaan tersebut. PT. Bayan Resources memiliki ROA yang sangat bagus terjadi pada tahun 2010 dan 2011, Tetapi pada tahun 2012 sampai 2013 memiliki ROA yang cenderung menurun diakibatkan laba tersebut menurun dan mengakibatkan peringkat obligasi yang ikut menurun setiap tahunnya.

PT. Timah Persero memiliki ROA yang meningkat setiap tahunnya namun pada tahun 2013 ROA tersebut cenderung menurun yang mengakibatkan peringkat obligasi juga ikut menurun. PT. Indo Tambang Raya Megah memiliki ROA yang sangat bagus setiap tahunnya. Namun, pada tahun 2014 ROA tersebut menurun sebesar 10,88 karena terjadi penurunan penjualan pada tahun tersebut yang mengakibatkan laba juga ikut menurun. PT. Perusahaan Gas Negara memiliki ROA yang sangat bagus dan terjadi penurunan pada tahun 2014 sebesar 0,85 ini sangat berpengaruh terhadap peringkat obligasi tersebut.

Hasil penelitian ini sesuai dengan penelitian N. Agus Sunarjanto dan Daniel Tulasi (2013) yang menyatakan Return on Assets berpengaruh positif terhadap peringkat obligasi. Sedangkan hasil penelitian Riris Christina Silaban dan Kardinal, SE., MM yang menyatakan Return On Assets menunjukkan hasil berpengaruh negatif terhadap peringkat obligasi

\section{b. Pengaruh Total Assets Turnover Terhadap Peringkat Obligasi}

Rasio ini menunjukkan kemampuan perusahaan untuk memenuhi semua kewajiban baik jangka panjang maupun jangka pendek yang jatuh tempo.

Pada umumnya Total Assets Turn Over merupakan rasio yang menunjukkan efektivitas penggunaan seluruh harta perusaahaan dalam rangka menghasilkan penjualan atau 
menggambarkan berapa rupiah penjualan bersih yang dapat dihasilkan oleh setiap rupiah yang diinvestasikan dalam bentuk harta perusahaan. Kalau perputarannya lambat, ini menunjukkan bahwa aktiva yang dimiliki terlalu besar dibandingkan dengan kemampuan untuk menjual.

Total Assets Turn Over berpengaruh negatif tidak signifikan terhadap peringkat obligasi. Dalam penelitian ini pertumbuhan Total Assets meningkat setiap tahun. Namun peningkatan pada pertumbuhan Total Assets ini tidak disertai dengan peningkatan pada penjualan perusahaan. Minimnya kontribusi penjualan dalam meningkatkan peringkat obligasi menyebabkan Total Assets Turn Over berpengaruh negatif terhadap peringkat obligasi.

Total Assets Turn Over yang dimiliki oleh perusahaan Pertambangan setiap tahunnya sangat rendah. Ini dipengaruhi oleh penjualan perusahaan yang setiap tahunnya semakin menurun akan tetapi aktiva yang diinvestasikan semakin meningkat. Ini juga dipengaruhi variabel makro (inflasi) yang berimbas secara tidak langsung pada perusahaan. Berdasarkan penelitian Juarsa (2015:192) Jika perputaran aset perusahaan lambat, berarti aset yang dimiliki terlalu besar dibandingkan dengan penjualan, sebaliknya jika perputaran aset perusahaan cepat, berarti aset yang dimiliki sedikit dibandingkan dengan penjualan yang dilakukan perusahaan. Jika semakin tinggi rasio ini maka kondisi perusahaan baik bagi investor untuk berinvestasi atau perusahaan dianggap memiliki kemampuan dalam membayar kewajibannya pada waktu jatuh tempo.Perputaran total aset (Total Asset Turnover).

Gambar 2. Grafik Tren Total Asset Turnover

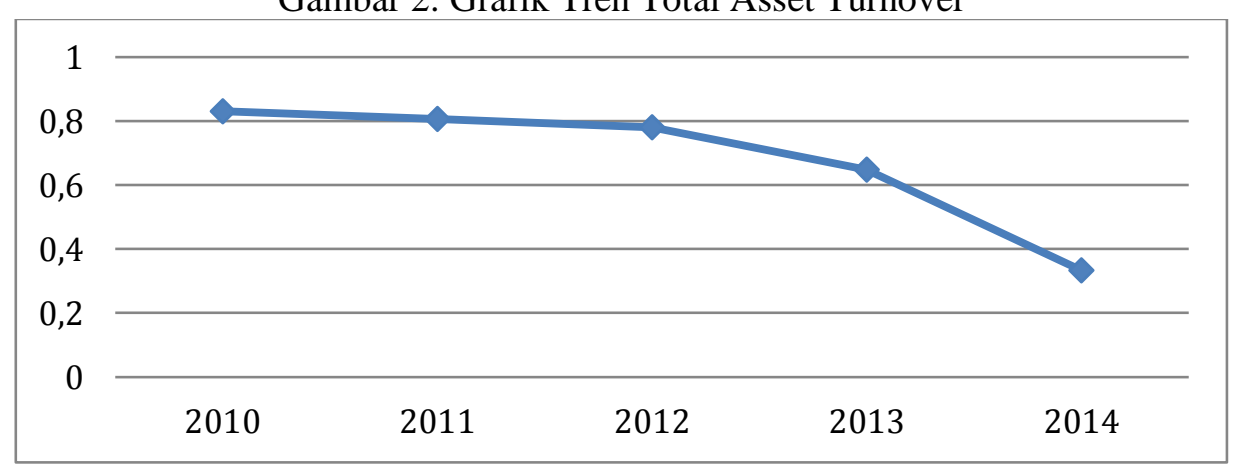

Sumber : data olahan

Berdasarkan grafik diatas, dapat kita lihat jelas bahwa rata-rata TAT pada perusahaan pertambangan mempunyai yang semakin menurun, artinya dalam laju perputaran aset yang dimiliki perusahaan, tren ini menunjukan bahwa perusahaan tidak memiliki konsistensi dalam menjaga aktivitas asset yang mereka miliki. Hal ini diperkuat oleh pernyataan Juarsa (2015:201) Jika perputaran aset perusahaan lambat, berarti aset yang dimiliki terlalu besar dibandingkan dengan penjualan, sebaliknya jika perputaran aset perusahaan cepat, berarti aset yang dimiliki sedikit dibandingkan dengan penjualan yang dilakukan perusahaan. Jika semakin tinggi rasio ini maka kondisi perusahaan baik bagi investor untuk berinvestasi atau perusahaan dianggap memiliki kemampuan dalam membayar kewajibannya pada waktu jatuh tempo.

PT. Aneka Tambang Persero memiliki TAT yang cenderung menurun setiap tahunnya dan memiliki kontribusi yang minim bagi perusahaan. Sehingga menyebabkan variabel TAT tidak berpengaruh terhadap peringkat obligasi. Pada PT. Adaro Energy memiliki TAT yang juga cenderung menurun setiap tahunnya, tetapi pada tahun 2011 memiliki TAT yang meningkat sebesar 0,70 ini diakibatkan total aktiva dan total penjualan tersebut mengalami peningkatan yang sangat berpengaruh terhadap peringkat obligasi. PT. Bumi Resources memiliki TAT yang cukup buruk sekali setiap tahunnya. Besarnya hutang yang dimiliki perusahaan, sedangkan laju perputaran aktiva melambat sehingga terjadi penurunan yang drastis pada peringkat obligasi tersebut, dan pada tahun 2014 perusahaan tersebut memiliki TAT yang sangat rendah sebesar 0,23 . 
Pada PT. Medco International Energi memiliki TAT yang cukup bagus setiap tahunnya. Tetapi pada tahun 2012 sampai 2014 Rasio TAT cendrung menurun setiap tahunnya karena perusahaan tersebut memiliki penjualan yang rendah dan total aktiva yang sangat tinggi sehingga tidak mengimbangi dengan laba perusahaan tersebut. PT. Elnusa memiliki TAT yang buruk ini disebabkan pertumbuhan penjualan dan pertumbuhan aktivanya tidak seimbang sehingga terjadi penurunan pada peringkat obligasi tersebut.

PT. Bukit Asam memiliki TAT yang baik setiap tahunnya namun pada tahun 2014 TAT menurun sebesar 0,53 dan menyebabkan menurunnya peringkat obligasi. Kondisi tersebut juga dialami oleh PT. Energi Mega Persada, Rasio TAT yang dimiliki cenderung menurun setiap tahunnya. PT. Bayan Resources memiliki TAT yang sangat bagus terjadi pada tahun 2010 dan 2011. Tetapi pada tahun 2012 sampai 2013 memiliki TAT yang cenderung menurun. Hal ini disebabkan perolehan laba menurun dan mengakibatkan peringkat obligasi yang ikut menurun setiap tahunnya.

PT. Timah Persero memiliki TAT yang sangat menurun setiap tahunnya ini dikarenakan penjualan tersebut sangat kecil dibandingkan total aktiva sehingga menyebabkan variabel TAT tidak berpengaruh terhadap peringkat obligasi, sedangkan PT. Indo Tambang Raya Megah memiliki TAT bagus setiap tahunnya, disebabkan penjualan tersebut lebih besar dibandingkan total aktiva dan mengakibatkan peringkat obligasi naik setiap tahunnya. Namun, pada tahun 2014 TAT tersebut menurun sebesar 0,71 karena terjadi penurunan penjualan pada tahun tersebut yang mengakibatkan laba juga ikut menurun. PT. Perusahaan Gas Negara memiliki TAT menurun drastis sebesar 0,30 yang mengakibatkan terjadi juga penurunan pada peringkat obligasi.

Penelitian ini bertentangan dengan hasil penelitian Silva \& Sri Mega (2018:8) menyatakan bahwa TAT berpengaruh terhadap peringkat obligasi, karena perusahaan dapat menunjukkan kemampuan dalam mengukur keefektifan total aset yang dimiliki perusahaan untuk mengukur berapa jumlah penjualan yang akan dihasilkan dari setiap rupiah yang tertanam dalam total aset. Selain itu mampumemenuhi kewajibannya juga akan memberikan daya tarik kepada investoruntuk menanamkan investasi pada perusahaan

c. Pengaruh Kepemilikan Institutional berpengaruh terhadap peringkat obligasi

Kepemilikan institusi menggambarkan persentase saham yang dimiliki oleh investor institusional yang berasal dari sektor keuangan yaitu perbankan, perusahaan efek, asuransi, dan lembaga pembiayaan.

Kepemilikan institutional dalam penelitian ini berpengaruh negatif tidak signifikan. Ini disebabkan oleh kecil kepemilikan institusi pada perusahaan. Perusahaan ini lebih tertarik meningkatkan perusahaan pada investasi jangka pendek dan jangka panjang. Peningkatan ini tercermin dalam assets yang dimiliki perusahaan yang meningkat setiap tahunnya. Para investor lebih melihat kemampuan perusahaan dalam meningkatkan kinerja perusahaan dengan investasi yang dilakukan.

Kepemilikan institutional yang dimiliki oleh perusahan Pertambangan setiap tahunna sangat rendah. Ini disebabkan oleh saham institusi yang dimiliki perusahaan tersebut sangat rendah. Sehingga tidak memiliki kontribusi dalam meningkatkan peringkat obligasi.

Hasil penelitian ini tidak konsisten dengan teori Gitman (2009) yang menyatakan corporate governance merupakan salah satu variabel monitoring dan pengendali kegiatan perusahaan sehingga bisa menjadi alat prediktor peringkat obligasi perusahaan. Kemungkinan perbedaan ini disebabkan karena penelitian ini menggabungkan variabel rasio keuangan dengan corporate governance secara bersama sehingga mungkin terjadi multikolinearitas antar variabel independen. Argumentasi lainnya, perbedaan obyek penelitian, periode penelitian, dan teknik analisis statistik menjadi bisa menjadi dasar adanya perbedaan hasil ini (Agus \& Daniel, 2013:240) 


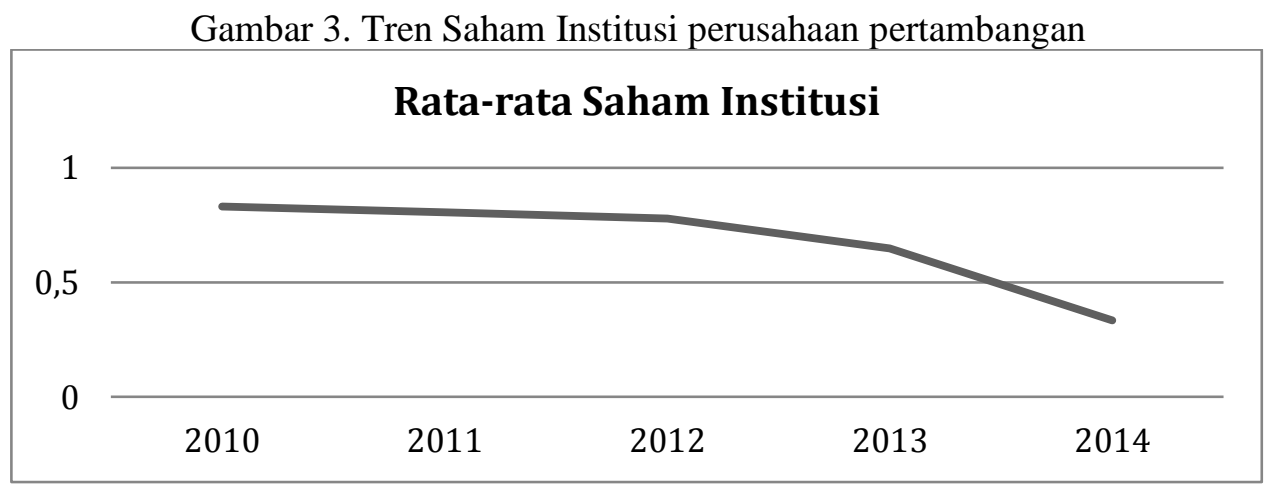

Sumber : Data Olahan

Dari grafik diatas menunjukan bahwa grafik saham Institusi cendrung menurun. Hal ini disebabkan berbagai faktor yang fundamental. Salah satunya Principal Investor, dimana penurunan saham instutusi tersebut mengindikasinya kegagalan perusahaan dalam menjaga kepercayaan saham kepemilikan Instusional yang berada didalam perusahaan.

Menurut Irham (2011:144), Trend yang terus mengalami penurunan terjadi karena kepercayaan publik (Investor) terhadap produk perusahaan tersebut terus mengalami penurunan, dan jika ini tidak diatasi dengan segera memungkinkan garis tren penurunan tersebut akan menyentuh titik terendah. Beberapa kondisi secara umum yang terjadi pada perusahaan, diantaranya kurangnya evaluasi kinerja secara keseluruhan. Kemudian minimnya kebijakan efesiensi dan efektivitas dalam mempertimbangkan Risk management modrn dan aspiratif yang perlu diterapkan. Trend yang positif akan membantu dalam memaksimalkan keuntungan pada perusahaan. Berdasarkan penelitian Fenni \& Dewi (2013:334) profitabilitas tinggi maka obligasi tersebut masuk pada investment grade, karena pendapatan operasi yang tinggi mengindikasikan bahwa perusahaan bekerja dengan efisisen

Corporate governance timbul karena kepentingan perusahaan untuk memastikan kepada pihak penyandang dana (principal/investor) bahwa dana yang ditanamkan digunakan secara tepat dan efisien. Selain itu dengan corporate governance, perusahaan memberikan kepastian bahwa manajemen (agent) bertindak yang terbaik demi kepentingan perusahaan (Agus \& Daniel, 2013:233)

PT. Aneka Tambang Persero tidak memiliki angka Kepemilikan Institutional. Hal ini disebabkan sebagian besar saham tersebut dimiliki oleh perusahaan itu sendiri dan dimiliki oleh manajemen perusahaan tersebut. Ini menyatakan bahwa kepemilikan institutional pada perusahaan tersebut tidak ada. PT. Adaro Energy memiliki Kepemilikan Institutional yang cenderung tetap setiap tahunnya ini disebabkan kinerja perusahaan tersebut baik dan tidak berubah dalam menghasilkan laba dan sangat mempengaruhi peringkat obligasi. Pada PT. Bumi Resources memiliki Kepemilikan Institutional yang cukup baik dan meningkat setiap tahunnya. Hal ini disebabkan kinerja perusahaan tersebut sangat baik dalam menghasilkan laba perusahaan tersebut.

PT. Medco International Energi memiliki Kepemilikan Institutional yang cenderung menurun setiap tahun. Karena saham institusi tersebut rendah sedangkan pada saham beredar semakin meningkat. Peningkatan ini disebabkan oleh variabel lain yang tidak termasuk dalam struktur kepemilikan dan mengakibatkan peringkat obligasi menurun.

PT. Bukit Asam juga tidak memiliki angka Kepemilikan Institutional. Hal ini disebabkan sebagian besar saham tersebut dimiliki oleh perusahaan itu sendiri dan dimiliki oleh manajemen perusahaan tersebut. Ini menyatakan bahwa kepemilikan institutional pada perusahaan tersebut tidak ada. PT. Bayan Resources juga memiliki Kepemilikan Institutional yang cenderung tetap setiap tahunnya ini disebabkan kinerja perusahaan tersebut baik dan tidak berubah dalam menghasilkan laba dan sangat mempengaruhi peringkat obligasi. Pada PT. Timah Persero juga 
tidak memiliki angka Kepemilikan Institutional. Hal ini disebabkan sebagian besar saham tersebut dimiliki oleh perusahaan itu sendiri dan dimiliki oleh manajemen perusahaan tersebut. Ini menyatakan bahwa kepemilikan institutional pada perusahaan tersebut tidak ada. PT. Indo Tambang Raya Megah juga memiliki Kepemilikan Institutional yang cenderung tetap setiap tahunnya ini disebabkan kinerja perusahaan tersebut baik dan tidak berubah dalam menghasilkan laba dan sangat mempengaruhi peringkat obligasi. PT. Perusahaan Gas juga tidak memiliki angka Kepemilikan Institutional. Hal ini disebabkan sebagian besar saham tersebut dimiliki oleh perusahaan itu sendiri dan dimiliki oleh manajemen perusahaan tersebut. Hal ini menyatakan bahwa kepemilikan institutional pada perusahaan tersebut tidak ada.

Penelitian ini didukung oleh penelitian Agus dan Daniel (2013:240) dimana kepemilikan institutional berpengaruh negatif tidak signifikan terhadap peringkat obligasi. Penelitian ini bertentangan dengan penelitian Adhi Prasetyo (2010) dimana kepemilikan institutional berpengaruh positif dan tidak signifikan.

\section{KESIMPULAN DAN SARAN}

a) Kesimpulan

Berdasarkan uraian dan analisa yang telah dikemukakan, maka secara garis besar dapat disimpulkan sebagai berikut:

Berdasarkan Regresi Logistik menunjukkan bahwa Total Assets Turn Over dan Kepemilikan Institutional tidak berpengaruh secara signifikan terhadap peringkat obligasi. Sedangkan Return On Assets berpengaruh secara signifikan terhadap Peringkat Obligasi.

b) Saran

Adapun saran yang dapat Penulis berikan kepada peneliti mendatang melalui hasil penelitian ini adalah sebagai berikut:

1. Bagi penelitian selanjutnya, diharapkan mau melakukan penelitian kembali mengenai peringkat obligasi dengan menggunakan variabel independen dan jumlah sampel yang lebih banyak lagi dan menggunakan satu tahun periode penelitian guna mendapatkan suatu kesimpulan yang lebih pasti variabel independen mana yang sangat berpengaruh terhadap peringkat Obligasi.

2. Bagi para emiten atau perusahaan yang menerbitkan obligasi sebaiknya mampu menjaga stabilitas keuangannya sehingga calon investor tertarik untuk membeli obligasi yang diterbitkan oleh perusahaan.

Bagi para investor sebelum membeli suatu obligasi maka harus memperhatikan keadaan perusahaan apakah perusahaan yang akan diberi investasi berstatus sehat guna menghindari resiko gagal bayar.

\section{DAFTAR PUSTAKA}

Agustin, Hamdi. 2012. Manajemen Keuangan (Revisi). UIR press. Pekanbaru

Badri, Juarsa. 2015. Pengaruh Debt To Equity Ratio (Der), Total Aset Turnover (Tat), Current Ratio (Cr) Terhadap Peringkat Obligasi Pada Perusahaan Yang Terdaftar di BEI. Jurnal Ekonomi STIE Haji Agus Salim Bukittinggi Vol. XVIII, No. 2, September 2015.

Berk, J. \& De Marzo, P. 2007. Corporate Finance. Addison. Wesley Boston.

Christine, Silva dan Sri Megawati Elizabeth. 2019. Analisis Pengaruh Current Ratio, Return On Asset, Debt To Equity Ratio Dan Total Asset Turnover Terhadap Peringkat Obligasi Perusahaan Food And Beveragedi Bursa Efek Indonesia Periode 2010 - 2017. Jurusan ManajemenSTIE Multi Data Palembang. 
Fahmi, Irham. 2011. Analisis Kinerja Keuangan. Cetakan pertama. Jakarta: Alfabeta.

Fahmi, Irham. 2013. Rahasia Saham dan Obligasi. Cetakan Pertama. Jakarta: Alfabeta.

Utami, Ayu Gandar. 2012. Mekanisme Corporate Governance Terhadap Peringkat Obligasi . Accounting Analysis Journal. Universitas Negeri Semarang

Gitman. 2009. Principles of Managerial Finance. 12th Edition. Boston: Prentice-Hall Investor.

Hakim, Lukman. 2019. Pengaruh Return On Asset, Investment Opportunity Set Dan Good Corporate Governance Terhadap Nilai Perusahaan Lq45 . IQTISHADUNA: Jurnal Ilmiah Ekonomi Kita Juni 2019, Vol.8, No.1: 33-42. Sekolah Tinggi Ilmu Ekonomi (STIE) Syariah Bengkalis.

Hartono, 2009. Teori Portofolio dan Analisis Investasi. Yogyakarta: Penerbit BPFEUGM

Rahardjo, Sapto. 2003. Panduan Investasi Obligasi. PT Gramedia Pustaka Utama,Jakarta

Sufiyanti, Fenni dan Dewi Kusuma Wardani. 2013. Dampak Rasio Keuangan Terhadap Peringkat Obligasi Pada Perusahaan Yang Terdaftar Di Bursa Efek Indonesia. Syariah Paper Accounting FEB UMS. Universitas Sarjawawiyata Tamansiswa.

Sunarjanto, N. Agus dan Daniel Tulasi. 2013. Kemampuan Rasio Keuangan Dan Corporate Governance Memprediksi Peringkat Obligasi Pada Perusahaan Consumer Goods. Jurnal Keuangan dan Perbankan, Vol.17, No.2 Mei 2013, hlm. 230-242. Fakultas Bisnis Unika Widya Mandala Surabaya. 